\title{
External Debt and Economic Growth in Nigeria: Empirical Insights from the Bound Testing Approach
}

\author{
Olukemi Olumuyiwa Olowe $(\mathrm{PhD})$ \\ Department of Economics, McPherson University, Seriki-Sotayo, Nigeria
}

\begin{abstract}
This study investigates the effect of external debt stock on economic growth in Nigeria for the period of 19812017. The paper used Augmented Dickey Fuller to test the unit root test and Autoregressive Distributed Lagged Model (ARDL) to find the long-run relationship and estimate both short and long run estimates. Real GDP was regressed on external debt stock, debt service payment, exchange rate, gross capital formation and labour force. The result found that the short-run parameter of the external debt stock and labour force was found positive and statistically significant at 5\% indicating their influence on output growth in the short-run, whereas debt service payment, exchange rate and gross capital formation were also significant in the period but has a negative effect on output growth in the short-run. The result also found that in the long-run external debt stock has a negative impact on economic growth while debt service payment, exchange rate, gross capital formation enhances economic growth. Thus, there is need for government to ensure that funds sourced from external borrowings were used for capital investment that can pay itself back with its interest and not recurrent expenses in order to ensure sustainable and pro-poor growth.
\end{abstract}

Keywords: External debt stock, debt service, investment, labour, exchange rate, real income

DOI: $10.7176 / \mathrm{JESD} / 10-12-08$

Publication date:June $30^{\text {th }} 2019$

\section{Introduction}

This paper unravels the nature of the relationship existing between external debt and economic growth in Nigeria. The need to investigate the direction between them resulted from the followings. First, the country's debt stock is increasing at an alarming rate as her external debt stock presently increased by $42.69 \%$ from $\$ 4.527$ trillion in 2017 to $\$ 6.46$ trillion in 2018 (Debt Management Office, 2019). Also, the total debt as at September 2018 stood at $\$ 22.43$ trillion with a growth rate of $85.06 \%$ compared to her outstanding in 2015 which stood at $\$ 12.12$ trillion (Leadership, 2019). More so, the Central Bank of Nigeria (CBN) reported that the cost of servicing public debt increased by $37.04 \%$ from $\$ 687.37$ billion in June, 2017 to $\$ 941.99$ billion in June 2018 (The Cable, 2019). In the recent time, a senior resident representative of International Monetary Fund, Amine Mati, said the country is presently diverting more of her resources to pay interest with over $50 \%$ of her revenue to service debt (The Cable, 2019). According to Debt Management Office (2019), the repayment of external debt stood at US\$331.06 million, US\$353.09 million, US\$464.05 million and US\$1,472.04million in 2015, 2016, 2017 and 2018 respectively. Likewise, the CBN Governor after a two-day Monetary Policy Committee warned the Federal Government on its rising debt portfolio against the real GDP which stood at 1.8\% in the 3rd quarter of 2018 (Leadership, 2019) and an estimate 1.9\% in 2018 (African Development Bank, 2019).

Second, the Nigeria's debt stock has not translated to sustainable growth and pro-poor growth. Instead, the number of poor people is increasing on a daily basis as the African Development Bank (AfDB, 2019) revealed that nearly $80 \%$ of the country's population amounting to 152 million people live on less than $\$ 2$ a day (Tella and Alimi, 2016; Maku and Alimi, 2018). Despite the present administration's campaign against the rising public debt portfolio before the 2015 general election, it has also added tremendously to the nation's debt stock. It thus becomes pertinent to find out whether the country's debt stock contributes to the Nigerian economic growth or not? The scope of this study spans from 1981 to 2017.

Furthermore, previous studies have come up with different findings as they failed to clearly show the kind of relationship existing between external debt and economic growth. For instance, Some like Ali and Mustafa (2012), Boboye and Ojo (2012), Azam, Emirullah, Prabhakar and Khan (2013) Hassan, Sule and john (2015), and Mbah, Umunna and Agu (2016) etc. reported negative relationship while other such as Patenio and Tan-cruz (2007), Ijishar, Abu and Selvanathan (2015), Joseph and Godoo (2016), Udeh, Ugwu and Onwuka (2016), among others found direct relationship. Also, the study investigates if the relationship is either significantly positive or negative. Likewise, the study find out whether or not the debt servicing payment drags the level of economic growth rate in Nigeria due to her increasing debt portfolio. This paper is a country-specific study as its focus is on the Nigerian economy. Past studies have favoured country-specific study over cross-section studies because it mainly focuses on the country's characteristics unlike the cross-section studies that ignored important features of individual countries in the group.

Apart from the introductory section, other parts are grouped into four. The section two deals with the literature review. The methodology of the study is discussed in section three. Section four presents data analysis and 
discussions while the last section concludes and proffers policy options.

\section{Literature Review}

Several scholars have sought to investigate the implication and impact of external debt on economic growth of various economies of the world, and different results has been obtained. Atique and Malik (2012) examined the impact of domestic debt and external debt on the economic growth of Pakistan separately over the period of 19802010.They employed the use of Ordinary Least Square (OLS) approach to Cointegration, unit root testing, serial correlation testing, test for checking heteroskedasticity and CUSUM test of stability. The result of their findings suggested an inverse relationship between domestic debt and economic growth. The results of their findings also show an inverse relationship between external debt and economic growth. These relationships were found to be significant as well. The results also concluded that external debt amount slows down economic growth more as compared to domestic debt amount. The negative effect of external debt is stronger on the economic growth in comparison to domestic debt. Some policy implications for coming out of debt overhang scenario were also presented. Similarly, Azam, Emirullah, Prabhakar and Khan (2013) investigated the role of debt in economic growth in Indonesia. The method of least square was used for parameters of estimation. The main result of the study shows external debt has a negative impact on economic growth during the period.

However, Abu and Selvanathan (2015) analyses the extent to which the external debt burden impacts on gross domestic product (GDP) of highly indebted poor countries over the period 1970-2007. The results of the findings of empirical analysis suggested that, in the short-run as well as in the long-run, a reduction in debt stock would have significantly increased the growth performance of the indebted nations. Likewise, Patenio and Tan-cruz (2007) investigated on the relationship between economic growth and external debt service payments of the Philippines using a quarterly data for the period of 1981-2005. Considering other explanatory variables such as capital stock, labor force, and human capital, it investigates the relationship between debt servicing and economic growth with the use of the vector autoregressive (VAR) representation, wherein the VAR model was used, it was revealed that debt servicing in the Philippines is not that high for debt overhang to occur. Results of the study using VAR model shows that economic growth is not very much affected by external debt servicing. Instead, it was found that capital stock has a strong relationship with economic growth. In debt overhang theory, it was mentioned that debt servicing will decrease economic growth because investors will be discouraged to invest. Capital variable in this study represents investments and since it was proven that capital has a great effect on growth, high external debt is supposed to have an alarming effect in the country. However, external debt servicing did not show a large effect on economic growth. This is probably because external debt servicing in the Philippines is not high enough for debt overhang to occur.

For Nigerian studies, Ajayi and Oke (2012) carried out a study which investigated the effect of the external debt burden on economic growth and development of Nigeria .It adopted regression analysis of OLS on secondary data sourced from CBN, Economical and Financial review, Business times, Financial Standard and relevant publication from Nigeria on variables like National Income, Debt Service Payment, External Reserves, Interest rate among others. The result of the findings indicates that external debt burden had an adverse effect on the nation's income and per capita income of the nation. High level of external debt led to devaluation of the nation's currency, increase in retrenchment of workers, continuous industrial strike and poor educational system. This led to the economy of Nigeria getting depressed. Based on the findings, the study suggests that debt service obligation should not be allowed to rise than foreign exchange earnings and that the loan contracted should be invested in profitable venture, which will generate a reasonable amount of money for debt repayment. Also, Ali and Mustafa (2012) investigated the external debt accumulation and its impacts on economic growth in Pakistan. The study carried out its analysis using the time series data covering the period of 1970-2010. The analysis was carried out using the econometric technique Augmented Dickey-Fuller (ADF) and the findings shows that higher accumulation of external debt discourages economic growth.

Furthermore, Mbah, Umunna and Agu (2016) carried out a research on the impact of external debt on growth in Nigeria an ARDL bound testing approach. The scope of the study covers the period of 1970-2013. Dual gap theory, Debt Overhang theory, Debt Laffer curve and crowding out hypothesis theory were employed. The estimation techniques employed are the ARDL, error correction model, Granger causality test. The result of the findings indicates a long-run relationship among the variables. External debt has a negative and significant impact on output. Hassan, Sule and John (2015) examined the implications of external debt on the Nigerian economy using the dual-gap theory. The study covered the period from 1986-2013. Ordinary least square was employed as the technique of estimation. Findings reveal that, if the course of consistent borrowing is not curbed, the economy will slump further, resorting to surplus budgeting and igniting increases in unemployment, decreases in total investment, falling reserves, increased exchange rate, higher inflation and consequently increased poverty. Iyoha (1999) investigates the impacts of external debt on economic growth in sub-Saharan African countries using an econometric study and small macro econometric model estimated for 1970-1994. An important finding was the significance of debt overhang variables in the investment equation, suggesting that mounting external debt 
depresses investment through both a "disincentive" effect and a "crowding out" effect.

Studies that reported a direct relationship between external debt and economic growth in Nigeria were also reviewed. Udeh, Ugwu and Onwuka (2016) examined the External debt and economic growth in Nigeria using a time series data for the period of 1980-2013. The Ordinary least square and Augmented Dickey-fuller econometric method was used as the estimation technique. The findings discovered that external debt has a positive relationship with gross domestic product at short-run, but has a negative relationship at long-run. Also while external debt service payment had negative relationship with GDP, exchange rate had a positive relationship with it.

Also, Ijishar, Joseph and Godoo (2016) examined the relationship between external debt and economic growth in Nigeria from 1981 to 2014. The study used both descriptive and econometric tools. The analysis of unit root was performed using ADF and $\mathrm{Ng}$ and Perron on each of the variables and the result showed that all the variables were integrated at first difference. The study revealed positive impact of external debt on economic growth in Nigeria in the long-run only. However, external debt servicing had both long-run and short-run negative effect on economic growth in Nigeria. Growth in capital expenditure, growth rate of exports, and external debt stock had positive impact on economic growth while external debt servicing and interest rate were inversely related to the growth of the economy.

\section{Analytical Framework, Model Specification and Estimation Approaches}

The constant need to borrow from foreign sources arises from the recognized role of capital in developmental process of any nation. Sustainable economic growth requires a given level of savings and investment and in a case where it is not sufficient, it results in external borrowing. Herein lays the basis for the dual-gap analysis. The dualgap theory postulates that for development to occur, it requires investment which is a function of savings whereas the investment that requires domestic savings is not sufficient enough to ensure that development would take place. The dual- gap framework is coined from a national income accounting identity which states that excess investment expenditure over domestic savings is equivalent to the surplus of imports over exports (Alimi and Alese, 2017). Thus at equilibrium the following identities hold:

$$
\begin{aligned}
& I-S=M-X \\
& S-I=X-M
\end{aligned}
$$

Where: $I=$ Investment, $S=$ Savings, $M=$ Import, and $X=$ Export. The above equations show that the domestic resource gap $(S-I)$ is equal to foreign exchange gap $(X-M)$. An excess of import over export implies an excess of resources used by an economy over resources generated by it. This further implies that the need for foreign borrowing is determined overtime by the rate of investment in relation to domestic savings. The specification of a model is based on the available information relevant to the study and theoretical emphasis. This means that the formulation of an economic model is dependent on available information on the study as embedded in standard economic theory and other major empirical works, or else, the model would be theoretical. The model specified as in the work of (Ajayi and Oke, 2012) is adapted and re-specified as:

$$
R G D P=f(E D S, D S P, E X R, G C F, L F)
$$

Where; $R G D P=$ Real Gross Domestic Product, $E D S=$ External Debt Stock, $D S P=$ External Debt Service Payments, $E X R=$ Official Exchange Rate, $G C F=$ Gross Capital Formation, and $L F=$ Labour Force. The model is specified of its linear form:

$$
R G D P_{t}=\beta_{0}+\beta_{1} E D S_{t}+\beta_{2} D S P_{t}+\beta_{3} E X R_{t}+\beta_{4} G C F_{t}+\beta_{5} L F_{t}+\mu_{t}
$$

Where: $\beta_{0}=$ intercept of relationship in the model constant, $\beta_{1}-\beta_{5}=$ coefficient of each exogenous variable, $t=$ time, and $\mu=$ stochastic error term.

These relationships are mathematically represented as: $\beta_{1}<0, \beta_{2}<0, \beta_{3}>0, \beta_{4}>0$, and $\beta_{5}>0$. The gross domestic product is expected to be positive because there are other factors that determine the GDP aside from the ones stated in the model. The a'priori expectation is a negative relationship between gross domestic product and external debt stock i.e. the higher the external debt stock, the lower the economic growth. The expectation between gross domestic product and external debt service payments is a negative relationship i.e. the higher the debt service payments, the lower the economic growth. The study expects direct links between capital, labour force and exchange rate to gross domestic product.

The time series data covers the period of 37 years, 1981-2017. We first test the unit root test of our variables using the Augmented Dickey Fuller test. The study employs the Autoregressive Distributed Lag (ARDL) bounds test by Pesarran, Shin and Smith (2001) to examine the effects of external debt on economic growth in the long and the short run periods in Nigeria. The study tests the following null and alternative hypotheses that no cointegration or level relationship (null hypothesis) as against the alternate hypothesis that there is cointegration. The existence of cointegrating relationship among the variables is determined by testing the significance of the lag levels of the variables using the F-test. The calculated F-statistic is compared with the two critical values for the upper and lower bounds tabulated by Narayan (2004). Owing to the fact that the direction of cointegration is not 
a priori established, then each variable is normalized as dependent variable while the existence of level relationship is tested. Then, the study estimates both the short-run and long-run equation.

\section{Empirical Analysis and Discussion of Findings}

\subsection{Preliminary Analysis}

Table 1 presents the summary statistics of our variables. It shows the mean, standard deviation, skewness and peakedness of the variables used for analyzing the relationship between external debt and output growth in Nigeria. From the above table, we see that the mean for GDP (Gross Domestic Product), EDS (External Debt Stock), DSP (Debt Service Payments), EXR (Exchange Rate), GFCF (Gross Capital Formation), and Labour Force (LFT) are $4.0 \%, 4.97 \%, 38.92 \%, 78.63 \%, 3.42 \%$ and $5.24 \%$ respectively. More so, the table revealed the value of median to be for GDP, EDS, DSP, EXR, GFC, and LFT are 4.28\%, 5.79\%, 4.84\%, 92.34\%, $0.61 \%$ and 2.86\% respectively. The maximum and minimum values for GDP, EDS, DSP, EXR, GFCF and LFT are $33.74 \%$ \& $-10.75 \%, 46.57 \%$ $\& 62.65 \%, 817.15 \%$ \& $-84.94 \%, 253.49 \%$ \& $0.67 \%, 59.39 \%$ \& $-35.997 \%$ and $20.48 \% \& 1.92 \%$ respectively. The standard deviation for GDP, EDS, DSP, EXR, GFCF and LFT is 7.16, 18.2, 160.59, 71.8, 23.03 and 5.06 respectively.

Table 1: Summary Statistics

\begin{tabular}{lcccccc}
\hline & GDP & EDS & DSP & EXR & GFCF & LFT \\
\hline Mean & 4.000021 & 4.973450 & 38.91573 & 78.63379 & 3.422941 & 5.236835 \\
Maximum & 33.73578 & 46.56690 & 817.1532 & 253.4923 & 59.38751 & 20.48193 \\
Minimum & -10.75170 & -62.65769 & -84.94073 & 0.673461 & -35.99681 & 1.920112 \\
Std. Dev. & 7.160042 & 18.19922 & 160.5910 & 71.79463 & 23.02768 & 5.062294 \\
Skewness & 1.683789 & -1.362204 & 3.725127 & 0.384888 & 0.482481 & 1.714472 \\
Kurtosis & 10.08410 & 7.623804 & 17.65751 & 1.979018 & 2.890122 & 4.640916 \\
Jarque-Bera & 89.72395 & 42.00286 & 394.2588 & 2.384314 & 1.375536 & 21.07330 \\
Probability & 0.000000 & 0.000000 & 0.000000 & 0.303566 & 0.502697 & 0.000027 \\
Observations & 37 & 37 & 37 & 37 & 37 & 37 \\
\hline
\end{tabular}

Source: Author's computation (2019).

Furthermore, the skewness shows the asymmetry distribution of the series around its mean where the skewness of a normal distribution is zero. Positive skewness implies that the distribution has a long right tail and negative skewness implies that the distribution has a long left tail. From the above table we observe that RGDP and EXR both have positive skewness and as such they have long right tails whereas GEDS and DSP have negative skewness therefore they have long left tails. Kurtosis measures the peakedness or flatness of the distribution of the series. If the kurtosis is above three, the distribution is peaked or leptokurtic relative to the normal and if the kurtosis is less than three, the distribution is flat or platykurtic relative to normal. From Table 1 GDP, EDS DSP and LFT values exceeds three therefore it is peaked or leptokurtic while EXR and GCFC, are below three therefore they are flat or platykurtic. From the table above the Jarque-Bera for GDP, EDS, DSP, EXR, GFCF and LFT are $89.72,42.00,394.26,2.38,1.38$ and 21.07 correspondingly.

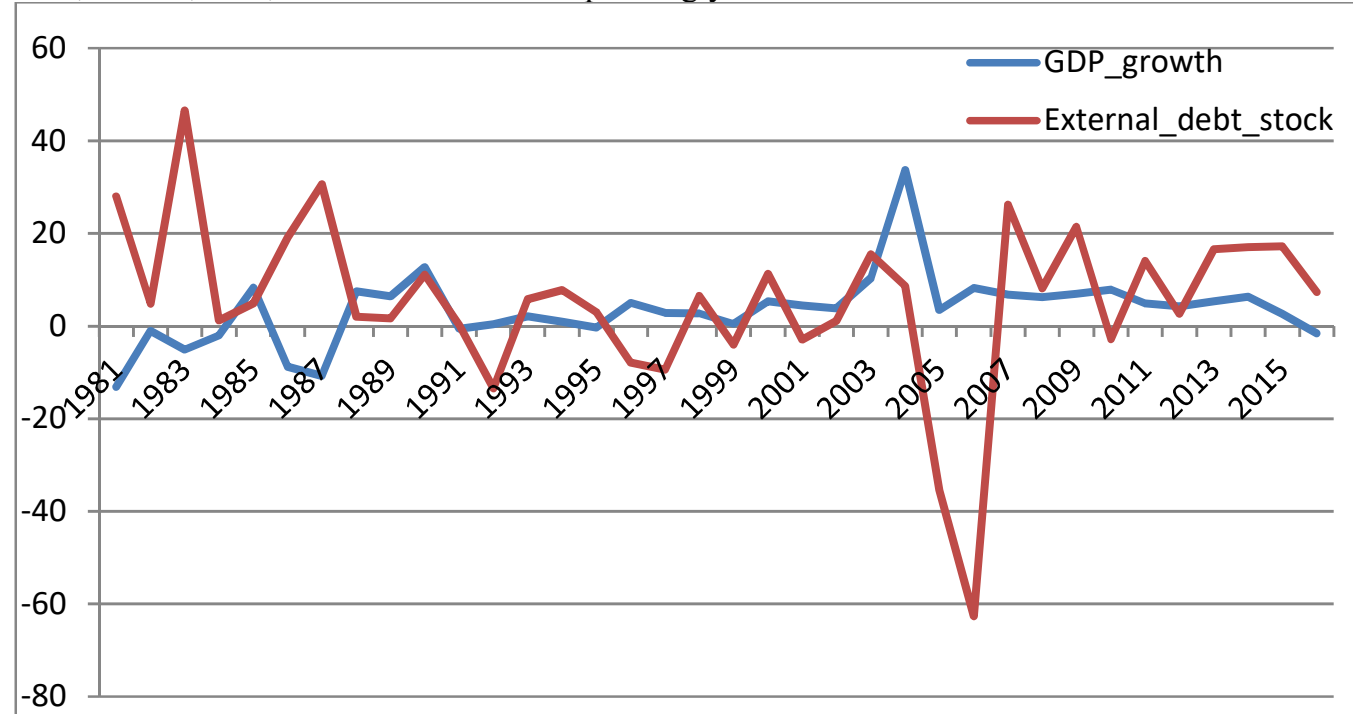

Figure 1: Growth Rate of GDP and External Debt Stock

The trend of external debt, control variables and economic growth in Nigeria for the period of 37 years, 19812017 were presented in Figures 1-5. The time series of these covariates (labour force, gross capital formation and 
exchange rate) are plotted against GDP as shown in Figures 1-5 respectively. Figure 1 revealed the time series plot of external debt and GDP in growth rate between 1981 and 2017. The figure indicates that Nigeria external debt reach its peak in 1983 with a growth percentage of 46.567 resulting in a negative growth of the national output with a growth percentage of -5.05. In 2006 external debt fell drastically with a percentage of -62.66 as a result of the debt relief with the Paris club under the regime of President Olusegun Obasanjo in which over $60 \%$ of Nigeria debt was cancelled (Adesoye, Adelowokan and Alimi, 2018).
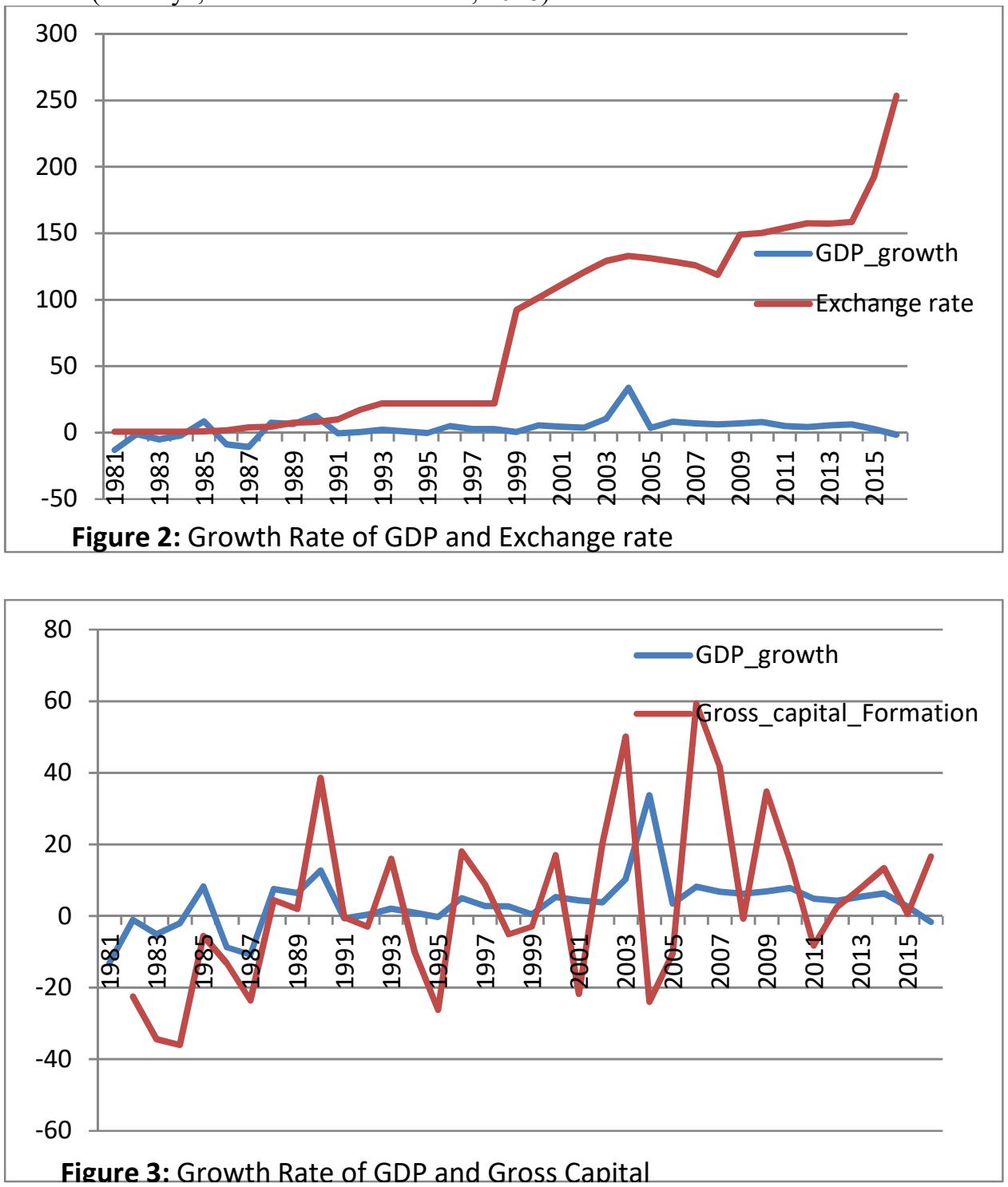

Figures 2 and 3 show the graphical flows of exchange rate and gross capital investment as they relate with gross domestic product. The chart revealed that exchange rate of Naira to US Dollar depreciate over the period against the fluctuating real output growth. However, the growth movements of both capital and real output fluctuate with almost similar movement indicating the significant of investment flow on output growth. 

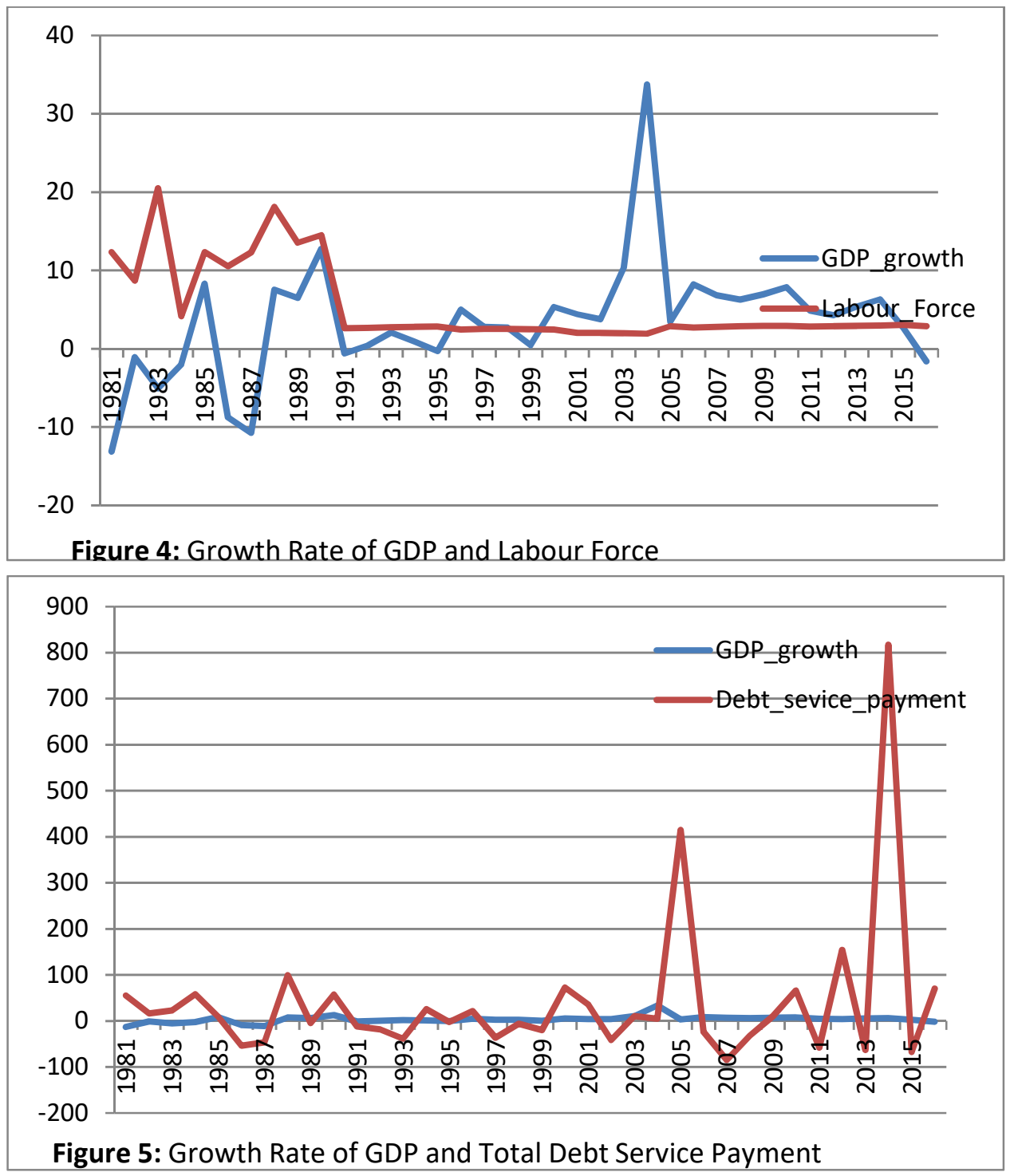

The last two figures (4 and 5) depict the graphical flow of how real output growth relate with both total debt service payment and labour force. The flows are similar to the explanation made in regards to Figures 4 and 5 . The chart does not indicate the exact direction of the explanatory variables to real output growth, thus, revealing the need to use appropriate estimation test to report their directions and magnitudes.

\section{Unit Root Test}

The unit root test tries to examine the stationarity of the variables. It is used to check for the presence of a unit root i.e. if the variables are not stationary at levels. This test is carried out using the Augmented Dickey Fuller (ADF) test. The results from the test are presented in Table 2. 
Table 2: ADF Test Results [Trend and Intercept]

\begin{tabular}{|c|c|c|c|c|c|}
\hline Variables & $\begin{array}{c}\text { ADF Stat at } \\
\text { level }\end{array}$ & Critical Value & $\begin{array}{l}\text { ADF Stat at } \\
\text { first diff. }\end{array}$ & Critical Value & Remarks \\
\hline & & $1 \%:-4.2529$ & & & \\
\hline GDP & $\begin{array}{l}-4.7228 \\
(0.0031)\end{array}$ & $\begin{array}{c}5 \%:-3.5485 \\
10 \%:-3.2071\end{array}$ & - & - & $\mathrm{I}(0)$ \\
\hline EDS & $\begin{array}{l}-4.8756 \\
(0.0021)\end{array}$ & $\begin{array}{c}1 \%:-4.2529 \\
5 \%:-3.5485 \\
10 \%:-3.2071\end{array}$ & - & - & $\mathrm{I}(0)$ \\
\hline DSP & $\begin{array}{l}-1.5751 \\
(0.7751)\end{array}$ & $\begin{array}{c}1 \%:-4.3561 \\
5 \%:-3.5950 \\
10 \%:-3.2335\end{array}$ & $\begin{array}{l}-6.2225 \\
(0.0001)\end{array}$ & $\begin{array}{c}1 \%:-4.3561 \\
5 \%:-3.5950 \\
10 \%:-3.2335\end{array}$ & $\mathrm{I}(1)$ \\
\hline EXR & $\begin{array}{c}-1.4555 \\
(0.8252)\end{array}$ & $\begin{array}{c}1 \%:-4.2529 \\
5 \%:-3.5485 \\
10 \%:-3.2071\end{array}$ & $\begin{array}{l}-3.9069 \\
(0.0230)\end{array}$ & $\begin{array}{c}\text { 1\%: }-4.2627 \\
5 \%:-3.5530 \\
10 \%:-3.2096\end{array}$ & $\mathrm{I}(1)$ \\
\hline GCF & $\begin{array}{l}-2.7673 \\
(0.2188)\end{array}$ & $\begin{array}{c}1 \%:-4.2733 \\
5 \%:-3.5578 \\
10 \%:-3.2124\end{array}$ & $\begin{array}{l}-10.934 \\
(0.0000)\end{array}$ & $\begin{array}{c}1 \%:-4.2733 \\
5 \%:-3.5578 \\
10 \%:-3.2124\end{array}$ & $\mathrm{I}(1)$ \\
\hline LF & $\begin{array}{l}-3.8882 \\
(0.0236)\end{array}$ & $\begin{array}{c}\text { 1\%: }-4.2529 \\
5 \%:-3.5485 \\
10 \%:-3.2071\end{array}$ & - & - & $\mathrm{I}(0)$ \\
\hline
\end{tabular}

Source: Author's computation (2019).

The a'priori expectation when using the ADF test is that a variable is stationary when the value of the ADF test statistic is greater than the critical value at 5\%. The gross domestic product (GDP), external debt stock (EDS), and labour force (LF) were found to reject the null hypothesis "it has unit root test" at level. This implies that series are stationary at levels. Thus, their series are integrated at order zero i.e. I(0). However, debt service payment (DSP), exchange rate (EXR), and gross capital formation (GCF) are not stationary at level but integrated at order one i.e., I(1). Therefore they were found not to reject the null hypothesis "no stationary" at level but after several iterations based on the number of lag length and differencing, the series were found to reject the null hypothesis at first difference. This indicates that the first-difference of those series is stationary.

\section{Co-integration Test}

This sub-section examines the long-run relationship between the dependent and independent variables using ARDL bound test in the stated hypotheses before the short-run and long-run estimates. For this model showing the relationship between external debt and economic growth, the ARDL bound test is employed because it $\mathrm{s}$ suitable for variables at different order of integration. The F-statistics estimate for testing the existence of longrun relationship between external debt and economic growth in Nigeria is presented in Table 3.

Table 3: Long-Run Relationship Using ARDL Bound Test $(4,4,3,4,4,3)$

\begin{tabular}{lcc}
\hline Test Statistic & Value & K \\
\hline F-statistics $(G D P \mid E D S D S P E X R$ GFC LFT) & 4.8510 & 5 \\
\hline Critical Value Bounds & & \\
\hline Significance $(G D P \mid E D S D S P E X R$ GFC LFT) & I(0) Bound & I(1) Bound \\
\hline $10 \%$ & 2.08 & 3 \\
$5 \%$ & 2.39 & 3.38 \\
$2.5 \%$ & 2.7 & 3.73 \\
$1 \%$ & 3.06 & 4.15 \\
\hline
\end{tabular}

Source: Author's computation (2019).

The estimated F-statistics of the normalized equations $\left(\mathrm{F}_{\mathrm{arb}}=4.8510\right)$ was greater than the lower and upper critical bound at $1 \%$ significance level. It implies that the null hypothesis of no long-run relationship is rejected at $5 \%$ significance level. The implication of the above estimation is that there is existence of long-run relationship between external debt and economic growth in Nigeria. The model has equilibrium condition that keeps the variables together in the long-run. 
Table 4: Results of Estimated ARDL Model

Dependent Variable: (GDP)

Selected Model: ARDL $(4,4,3,4,4,3)$

Sample: 19812017

\begin{tabular}{|c|c|c|c|c|}
\hline \multicolumn{5}{|c|}{ Short-Run Estimates } \\
\hline Variable & Coefficient & Std. Error & t-Statistic & Prob. \\
\hline$\Delta(\operatorname{GDP}(-1))$ & 3.024711 & 0.313689 & 9.642381 & 0.0006 \\
\hline$\Delta(\operatorname{GDP}(-2))$ & 1.349624 & 0.189060 & 7.138593 & 0.0020 \\
\hline$\Delta(\operatorname{EDS}(-1))$ & 0.709123 & 0.080773 & 8.779210 & 0.0009 \\
\hline$\Delta(\operatorname{EDS}(-2))$ & 0.981890 & 0.104790 & 9.370065 & 0.0007 \\
\hline$\Delta(\mathrm{DSP}(-1))$ & -0.730156 & 0.080360 & -9.086117 & 0.0008 \\
\hline$\Delta(\mathrm{DSP}(-2))$ & -0.575579 & 0.060807 & -9.465679 & 0.0007 \\
\hline$\Delta(\operatorname{EXR}(-1))$ & -0.075985 & 0.018334 & -4.144545 & 0.0143 \\
\hline$\Delta(\operatorname{EXR}(-2))$ & -0.130897 & 0.023828 & -5.493380 & 0.0054 \\
\hline$\Delta(\mathrm{GFC}(-1))$ & -2.005696 & 0.249301 & -8.045268 & 0.0013 \\
\hline$\Delta(\operatorname{GFC}(-2))$ & -0.913776 & 0.103482 & -8.830291 & 0.0009 \\
\hline$\Delta(\operatorname{LFT}(-1))$ & 4.069381 & 0.640466 & 6.353783 & 0.0031 \\
\hline$\Delta(\operatorname{LFT}(-2))$ & 1.604083 & 0.209577 & 7.653912 & 0.0016 \\
\hline ECT(-1) & -0.429713 & 0.046638 & -9.213726 & 0.0008 \\
\hline \multicolumn{5}{|c|}{ Long-run Estimates } \\
\hline EDS & -0.287720 & 0.042492 & -6.771125 & 0.0025 \\
\hline DSP & 0.211692 & 0.029458 & 7.186271 & 0.0020 \\
\hline EXR & 0.092231 & 0.016086 & 5.733617 & 0.0046 \\
\hline GFC & 0.452003 & 0.028077 & 16.09865 & 0.0001 \\
\hline LFT & 0.749263 & 0.124228 & 6.031371 & 0.0038 \\
\hline $\mathrm{C}$ & 4.081193 & 1.263699 & 3.229561 & 0.0320 \\
\hline & 0.9608 & F-stat & \multirow{2}{*}{\multicolumn{2}{|c|}{$\begin{array}{c}229.0185(0.0000) \\
1.945\end{array}$}} \\
\hline yared & 0.8784 & D-Watson & & \\
\hline
\end{tabular}

Source: Author's computation (2019).

\subsection{Results of the Long-Run and Short-Run Estimates}

The results presented in this section present the findings that answer the null hypothesis that external debt has no significant effect on the economic growth in Nigeria. This is reported for both the short-run and long-run relationship estimates between external debt, macroeconomic variables and economic growth in Nigeria using the estimated ARDL approach which was described extensively in the previous chapter. The approach is a composite of short-run and long-run estimates of the interrelationship among considered series in this study. The clear evidence of our empirical estimates from our indicators - external debt stock (EDS), debt service payment (DSP), and exchange rate (EX) and gross domestic product growth (GDP) are presented in Table 4. In the ARDL test, it automatically choose the lag length on all variables as the model was set at four to ensure sufficient degree of the freedom based on automatic selection of Akaike Information Criterion. The short-run estimates of the relationship between external debt and economic growth is presented in Table 4.

The coefficients of the short-run lag one and two of change in real output growth has positive and significant impact on the current changes in real output level at 5\%. It implies that the changes in real output measuring the level of economic growth in the first and second periods in the short-run dictates the current level of output growth in Nigeria. The short-run parameter estimates of external debt stock and labour force was found to be positive and statistically significant at $5 \%$ indicating that they influence changes in output growth in the short-run. The coefficients of debt service payment were significant but its effect on output growth was negative. Similarly, the coefficients of gross capital and exchange rate were negative and statistically significant at 5\% implying that exchange rate depreciation and low investment do not have positive impact on economic growth in the short run.

The short-run estimation results also show the error correction mechanism which measures the speed or degree of adjustment. This is the rate of adjustment at which the dependent variable changes due to changes in the independent variables. The coefficient of the ECT is found to be negative and statistically significant at the conventional level. The ECT value (-0.4297) implied that the model corrects its short-run disequilibrium by $42.97 \%$ speed of adjustment in order to return to the long run equilibrium.

The long-run estimates from Table 4 indicated that change in economic growth measures by real gross domestic product growth was negatively affected by change in external debt stock. The result shows that the indicator was not in tandem with the theoretical expectations as it fails to enhance output in the long-run. Also, on magnitude basis, $10 \%$ increase in external debt stock; change in output decreased by $2.88 \%$. As a result, the table 
reported that other indicators - debt service payment, exchange rate, gross fixed capital formation, and labour force have direct effects on change in output growth, which all conforms to a'priori expectations. A $10 \%$ increase in debt service payment, exchange rate, gross fixed capital formation, and labour force increase change in output growth by $2.12 \%, 0.92 \%, 4.5 \%$ and $7.49 \%$ correspondingly. In terms of partial significance, all indicators have significant effects on change in real output a measure of economic growth in Nigeria during the reviewed periods.

The coefficient of determination (Adjusted- $\mathrm{R}^{2}$ ) is high $(87.84 \%$ ) indicating that about $87.84 \%$ of the total variations in economic growth measured by change in real GDP was explained by the variables in the model. It simply indicated that the variation of changes in output was explained by $87.84 \%$ variations in explanatory indicators. The overall test using the F-statistic (229.0185) is statistically significant at 5\% level of significance showing that model is well specified and statistically significant. The Durbin Watson statistic (1.945) shows that there is absence of serial autocorrelation in the model.

\subsection{Diagnostic Test}

The estimated ARDL model is tested for heteroskedasticity, serial correlation, functional form misspecification, parameter stability and normality. The results from these tests are shown in the Table 5.

Table 5: Diagnostic Tests

\begin{tabular}{|l|l|}
\hline \multicolumn{2}{|l|}{ Model } \\
\hline Serial Correlation: $1.6516[0.1629]$ & Normality Test: $0.5946[0.7428]$ \\
\hline Functional Form: $0.6633[0.5284]$ & Heteroskedasticity Test: $0.3597[0.9750]$ \\
\hline
\end{tabular}

Source: Author's computation (2019).

The estimated ARDL model revealed that the models passed the serial correlation test indicating that the error terms are not correlated up to order 4. At the conventional rate, the null hypothesis of normality and heteroskedasticity tests were not rejected. It implies that the error terms are normally distributed and have same variance. Similarly, the functional form test using the Ramsey RESET tests were also satisfactory indicating that the ARDL model is not mis-specified.

\subsection{Discussion of Findings}

The result shows that external debt stock has positive impact on real output growth in the short-run while it has negative influence on output. It implies that the government reliance on external debt only support output growth within the shortest time period but fails to in the long-run because they fail to channel the fund into capital project that are able to pay itself back in the future. This is reflected on the high recurrent expenditure spending of the country and low spending on capital project. Likewise, this reflected on the sign of debt service payment as it reduces output in short-run while enhancing growth in long-run as the country is able to pay back its debt. The positive impact of labour force on growth shows the important of the country's population standing as its market base and its ability to generate more output. Investment growth was found to have positive impact on growth in long-run indicating that long-term capital can drive growth. The depreciation of Naira was also reported to drive growth indicating that this has been able to discourage import as importation becomes more expensive. This suggests that government should take this advantage to provide enabling environment for local investors to expand their production capacity so as to make their goods cheaper compare to the foreign commodities.

\section{Conclusion and Policy Options}

This research paper examines the effects of external debt stock on economic growth in Nigeria using a time series data spanning from 1981-2017. The study employed the Augmented Dickey Fuller to test the stationarity level of our variables which showed mixed result of integration at levels and first difference. This confirmed the appropriateness of the estimation techniques (autoregressive distributed lag) employed to estimate the long-run relationship and the short- and long- run parameters. The variables are real GDP, external debt stock, debt service payment, exchange rate, gross capital formation and labour force. The findings revealed that the short-run parameter of the external debt stock and labour force was found positive and statistically significant at $5 \%$ indicating their influence on output growth in the short-run, whereas debt service payment, exchange rate and gross capital formation were also significant in the period but has a negative effect on output growth in the shortrun. The result also found that in the long-run external debt stock has a negative impact on economic growth while debt service payment, exchange rate, gross capital formation enhances economic growth. It implies that the government reliance on external debt only support output growth within the shortest time period but fails to in the long-run because they fail to channel the fund into capital project that are able to pay itself back in the future. This is reflected on the high recurrent expenditure spending of the country and low spending on capital project. Likewise, this reflected on the sign of debt service payment as it reduces output in the short-run while enhancing growth in the long-run as the country is able to pay back its debt. As a result, there is need for government to ensure that funds sourced from external borrowings were used for capital investment that can pay itself back with its interest and not recurrent expenses in order to ensure sustainable and pro-poor growth. 


\section{References}

Abu, S. Selvanathan, E. A. \& Saroja, S. (2015). "The Impact of External Debt on Growth: Empirical Evidence from Highly Indebted Poor Countries", Discussion Paper 15.10

Adesoye, A. B., Adelowokan, A. O. \& Alimi, O. Y. (2018). Time series analysis of non-oil export demand and economic performance in Nigeria. Iranian Economic Review, 22(1), 295-314

African Development Bank (AfDB, 2018). Nigeria Economic Outlook. Accessed from https://www.afdb.org/en/countries/west-africa/nigeria/nigeria-economic-outlook/

Ajayi, M.B. and Oke, M.O (2012)."Effect of External Debt and Economic Growth and Development of Nigeria", International Journal of Business and Social Science, Vol.3 No 12.

Ali, R. \& Mustafa, U. (2012). "External Debt Accumulation and Its Impact on Economic Growth in Pakistan", The Pakistan Development Review 51:4 part II pp.79-96.

Alimi, O. Y. \& Alese, J. O. (2017). Comparative analysis of investment funding in the Nigerian oil and agricultural sector. International Journal of Economics and Accounting, 8(1), 67-82.

Atique, R. and Malik, K. (2012). "Impact of Domestic and External Debt on Economic Growth in Pakistan", World Applied Sciences Journal 20 (1) pp 120-129

Azam, M. Emirullah, C. Prabhakar, A. \& Khan, A. (2013). "The Role of External Debt in Economic Growth of Indonesia-A Blessing or Burden"?. Middle-East Journal of Scientific Research.18(8): 11-118.

Debt Management Office (2019). Nigeria's external debt stock as at December 31st, 2018. Accessed from https://www.dmo.gov.ng/debt-profile/external-debts/external-debt-stock/2761-nigeria-s-external-debtstock-as-at-december-31-2018/file

Hassan, M.O, Sule, A. \& Abu, J. (2015)."Implications of External Debt on the Nigerian Economy: Analysis of the Dual Gap Theory", Journal of Economics and Sustainable Development. Vol. 6 No. 13.

Ijishar, V.U, Joseph, F. \& Godoo, M. (2016). "The Relationship between External Debt and Growth in Nigeria", International Journal of Economic and Management Science, 6:360.

Iyoha, M.A (1999). "External Debt and Economic Growth in Sub-Saharan African Countries: An Econometric Study", AERC Research Paper 90, Nairobi.

Leadership (2019). Nigeria's rising debt profile. Accessed from https://leadership.ng/2019/02/06/nigerias-risingdebt-profile

Maku, O. E. \& Alimi, O. Y. (2018). Fiscal policy tools, employment generation and sustainable development in Nigeria. Acta Universitatis Danubius, 14(3), 186-199.

Mbah, A. Ummuna, G. \& Agu, C. (2016). "Impact of External Debt on Economic Growth in Nigeria: An ARDL Bound Testing Approach", Proceedings of the Fifth Middle-East Conference on Global Business, Economics, Finance and Banking. Paper ID:DF601

Narayan, P. K. (2004). Fiji's tourism demand: the ARDL approach to cointegration. Tourism Economics, 10(2), 193-206.

Patenio, J. A. \& Tan-cruz, A. (2007). "Economic Growth and External Debt Servicing of the Phillipines", $10^{\text {th }}$ National Convention on Statistics (NCS)

Pesaran, M. H., Shin, Y., \& Smith, R. J. (2001). Bounds testing approaches to the analysis of level relationships. Journal of applied econometrics, 16(3), 289-326.

Tella, S. A., \& Alimi, O. Y. (2016). Grassroots banking, microcredit and poverty reduction in developing countries: the case of Nigeria. A Paper presented at the LAPO Institute Conference on Microfinance.., in Benin City, Edo State on 17-18 August, 2016.

The Cable (2019). IMF: Over 50\% of Nigeria's revenue is used to service debt. Accessed from https://www.thecable.ng/oniha-global-market-volatility-affected-nigerias-debt-profile

Udeh, S. Ugwu, J. \& Onwuka, I. (2016).”External Debt and Economic Growth: The Nigeria Experience", European Journal of Accounting Auditing Finance Research, Vol. 4. No 2 pp33-48. 